\title{
The oldest illustration of Chinese crinoid calyx: annotated translation of “Cupressocrinus abbreviatus" reported by Fritz Frech in 1911
}

Jih-Pai Lin ${ }^{\mathrm{a}, *}$, Franz T. Fürsich ${ }^{\mathrm{b}}$

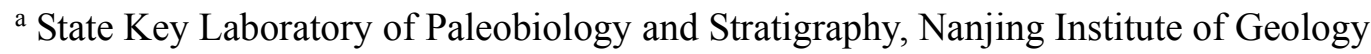
and Palaeontology, Chinese Academy of Sciences, Nanjing 210008, China

${ }^{\mathrm{b}}$ GeoZentrum Nordbayern, FG Paläoumwelt, Friedrich-Alexander-Universität Erlangen-Nürnberg, Loewenichstr. 28, Erlangen 91054, Germany

\begin{abstract}
The early history on the discovery of the first Chinese crinoid calyx of "Cupressocrinus abbreviatus" (now Halocrinites schlotheimii Steininger, 1831) remains unclear. The first record of "C. abbreviatus" was reported by Fritz Frech in 1911. It was included in the fifth and the last volume of the series titled China by the German traveler and explorer Ferdinand Freiherr von Richthofen. The cover page, title page, and prologue are informative; thus, they are explained and translated in detail. Richthofen's specimen is still the oldest documented cupressocrinitid calyx known in China today. Discovery of a second cupressocrinitid specimen confirms the existence of this family in China. Current taxonomic positions of the Chinese specimens are discussed.
\end{abstract}

Keywords: Crinoidea; Cupressocrinitidae; Ferdinand von Richthofen; Devonian; Yunnan

\footnotetext{
* Corresponding author. E-mail addresses: jplin@nigpas.ac.cn; jplin@hotmail.com Tel.: +86 25 83282274; fax: +862583282274
} 


\section{Introduction}

According to $\mathrm{Mu}$ (1948, p. 56), the first crinoid calyx described and illustrated from China was "Cupressocrinus abbreviatus" (= Halocrinites aff. schlotheimii Steininger, 1831; see Bohatý and Herbig (2010, p. 381); also see Webster and Webster (2014)). Because that paper was published shortly after the World War II, the original reference and foreign author's name in his native language was omitted in the publication in order to reduce printing space. Subsequently, an image of “Cupressocrinites abbreviatus" appeared in Tien and Mu (1955, pl. 48, fig. 12) with a text-figure (Tien and $\mathrm{Mu}, 1955$, text-fig. 33) showing a complete crown that is similar to the drawing in Wang et al. (1955, p. 232). They stated that the figured specimen was from the Devonian strata in Yunnan Province. The same specimen figure was reproduced first in Wang et al. (1956, p. 375), and then in the two volume-set Fossils of Yunnan Province by the Geological Bureau of Yunnan Province (Cao and Gui, 1974, pl. 76, fig. 3) for internal usage (not released to the public). $\mathrm{Mu}$ and $\mathrm{Wu}$ (1974) reported the new cupressocrinitid column taxon "Cupressocrinites yunnanensis" from the same unit (see 4. Taxonomy below). With discovery of the second calyx from Yunnan, Chen and Yao (1993) named a new species "Cupressocrinites deltoides" (see 4. Taxonomy below) and mentioned Frech's specimen quoting from Mu (1948), but misspelled the name as "Frich" (Chen and Yao, 1993, p. 65). Webster et al. (2009) re-examined the Chen and Yao's (1993) collection now deposited at the Nanjing Institute of Geology and Palaeontology, CAS, Nanjing.

After searching through the book collection in the Library of Nanjing Institute of Geology and Palaeontology, CAS (NIGP), the first author found the illustration in the work by Fritz Frech (1911) (Fig. 1A). This work was the fifth and the last volume of the famous series entitled China by the German traveler and explorer Ferdinand Freiherr von Richthofen (1833-1905), who visited China between 1868 and 1872 (Chang, 1937), and he coined the term "Silk Road" (or "Silk Route"). Based on the collection at NIGP, there are four out of five volumes present in the library. The first volume was published in 1877; the fourth volume in 1883; the fifth volume in 1911; and the third volume in 1912. Peng (2007) commented that Dames' (1883) and 
Kayser's (1883a, b) published in the fourth volume were among the earliest scientific studies on Chinese trilobites. Purposes of this study are to understand the history of the discovery and to provide a translation of the original description of the crinoid calyx in the fifth volume, and to provide a modern review on Chinese cupressocrinitids.

\section{China, Fifth Volume}

\subsection{Front cover}

The first author was attracted to this book because the front cover is very attractive (Fig. 1A). On close examination, it contains many characteristic Chinese symbols with special meanings. The center is a stone turtle carrying a tall stone tablet on its back against the back ground of clouds and mountains. The stone was inscribed with the title of the book "CHINA" and the name of the deceased master "F. V. RICHTHOFEN" in gold type. On the top of the cover, there is a dragon on the top-left corner and a phoenix on the top-right corner. Both mythological figures symbolize eternal life and good fortune in Chinese tradition. The stone turtle carrying a stone on its back is usually a type of tombstone or tablet that contains royal orders given by the emperor. The tablet can be 3-5 $\mathrm{m}$ tall in front of the grave and stands out distinctly. In the prologue, Frech (1911) mentioned Master Richthofen had visited Nanking (= Nanjing), where many stone turtles are present even today. For example, the Ming Dynasty tablet at the Chaotian Palace, Nanjing is six meters tall and was made between 1465 and 1487 (Fig. 1B). The overall design of the front cover of the book

essentially captures the core elements of Chinese tradition. Although there is no definite information about who designed the cover, there is a stamp with German words, which translate as "bookbinding by J. R. Herzog at Leipzig" inside of the back cover of the first volume published in 1877 with the same hardcover binding style.

\subsection{Title page}

The title page (Fig. 2) contains much useful information. It is translated as 
follows:

CHINA

\title{
RESULTS OF MY OWN JOURNEYS AND OF THE STUDIES THAT ARE BASED ON THESE
}

\author{
BY \\ FERDINAND FREIHERR [BARON] v. RICHTHOFEN
}

FIFTH VOLUME

contains the concluding paleontological study of the collections of F. VON

RICHTHOFEN, the investigation of additional fossil remains of the provinces he visited, and the sketch of an overview of the geological history of China

by

DR. FRITZ FRECH

with 31 plates of fossils, 3 geological-topographic map sketches and tables

BERLIN 1911

VERLAG VON DIETRICH REIMER (ERNST VOHSEN)

Notice that the illustrated copy had a stamp inscribed "Department of Geology, Shanghai Science Institute" on the top (Fig. 2). This was part of the library collection owned by the Japanese Colonial Research Institute - Shanghai Science Institute during the World War II (see the SSI label type in Lin, 2015). Richthofen's volumes on China were expensive and rare at that time; thus, not many libraries in China have it today. 


\subsection{Prologue}

As little information about this work is known among the Chinese geoscience community, the prologue and introduction of the fifth volume has been translated below.

In 1894, when making preparations for the study of South China, FERDINAND VON RICHTHOFEN handed over the fossils which he had collected near Nanking, in Shantung and at the Yangtsze to the author. Later on, the Paleozoic and Mesozoic faunas, which had not been dealt with during work on the fourth volume, were added. The immortal master had explained to me their occurrence repeatedly. Initially only a short paper has been published in the Neues Jahrbuch für Mineralogie as well as occasional remarks in my handbook on Earth History. Reasons for the slow progress were the differences between the Late Paleozoic rocks of central Europe and those of Asia. Only after the investigations of German researchers - C. DIENER, NoetLing and WaAgen - in Punjab and the high mountains of India elucidated to some extent these difficult aspects, it was possible to attempt the interpretation of the scattered occurrences with a chance of succeeding.

Apart from the purely scientific investigations, the identification of the Carboniferous and Dyadic [= Permian] fossils is closely tied to the economically important question about the age of the Chinese coal deposits. As the travels of FERD. VON RichthofEN were, to a large extent, directed at investigating their geological distribution, the paleontological investigation must be concentrated on this topic: The question, whether in China the same animal and plant guide fossils lead the way to the concealed deposits as in Europe is of such great 
national-economic and political importance that the content of the fourth and fifth volume ${ }^{(1)}$ of the present opus deals mainly with this question. As a remark in advance, despite the variety of the coal formations documented by the paleontologists in the fourth volume, the investigation of the last collections yielded an important addition of the Mesozoic fuel deposits, i.e., the documentation of the Lower Cretaceous coals in Sz'-tshwan.

(1) Only 13 out of the 54 plates in the fourth volume and 10 out of the 31 plates in the fifth volume depict older marine fossils.

An additional important change compared to the fourth volume - already clearly recognized by FERDINAND VON RICHTHOFEN in the field - is the proof that the great majority of the Chinese coals belong to the Dyas, others to the Lower Carboniferous; the occurrences in southern China, which correspond to the productive black coal formation of Europe, are exclusively marine ${ }^{(1)}$. Solely in Kansu LóczY found an Upper Carboniferous coal deposit and that of little importance. In the south of the empire, the uppermost Dyas is an important coal horizon.

The study of the late Paleozoic animals and plants was extremely voluminous; it was therefore impossible to treat the total fossil fauna monographically. The description of the Cambrian fauna would essentially be a repetition of the studies by MONCKE (for Shantung) and MANSUY (for Tongking). Therefore, I confine myself here to a short summary; also when presenting the late Tertiary mammals I shall give only a summary of the paleontological studies of KOKEN and SCHLOSSER. ZEILLER's investigations of the fossil plants of Tongking and 
southern China have only been repeated here in as far as new age determinations of the beds in which they were found changed the conclusions. Despite the great richness of paleontological treasures contained in the rest of the RICHTHOFEN collections, I could not confine myself to this material. Approximately at the same time as the first investigations, instigated by the explorer of China himself, EDUARD SUESS sent me the Paleozoic fossils collected by StOLICZKA and Bogdanowitsch in Central Asia for study, and L. VON LÓCZY, of outstanding merit due to his documentation of South and West China, bestowed the same trust on me. In addition, my own investigations of the middle Araxes between Eriwan and Djulfa, carried out together with my wife and G. VON ARTHABER in 1897, produced many results, important for the comparison with China.

Apart from collections mentioned just now I could investigate the fossils discovered by the geo-engineer ABENDANON and the geological councilor CREMER in Sz'-tshwan. To this the Paleozoic fossils brought by Dr. YABE to Europe must be added and, finally, the collections of the British Museum ${ }^{(2)}$, of the Ecoles des Mines ${ }^{(3)}$ and of the Sorbonne in Paris.

That despite the voluminous material some stratigraphic and many tectonic questions still await to be answered, especially in South China is best shown by the attempt to provide an overview on the geological history of China, which concludes the fifth volume. One aspect I noticed over and over again during my work - the unrivalled accurateness of observations of the deceased master. He often diagnosed the age of beds in the field more correctly than tedious paleontological research and, by combining just a few observations, commonly reconstructed the basic tectonics, before much later they were established as 
correct by extensive field work of successors.

Breslau [now Wroctaw], August 1911

F. FRECH

(1) Apart from the coal beds of Kwangtung which have not yet been precisely investigated from a paleontological point of view.

(2) Thanks to the courtesy of Dr. BATHER and S. WOODWARD they also were sent to Breslau.

(3) The material of DePRAT, LANTENOIS, MANSUY and ZEIL from South Yunnan and Tongking deposited in the collections have also been investigated by DouviLlé, MANSUY and ZEILleR. Individual faunas could be again investigated and compared with the remaining occurrences thanks to the kindness of Prof. Douvilléand Dr. Douvillé. I am particularly grateful to Dr. TIESSEN who went to extraordinary trouble to find out the locations of the place names that were very difficult to decipher. The results of the paleontological investigations are usable only due to his efforts.

\section{Original fossil description and illustration}

\subsection{Description}

The following description is translated from Frech (1911, pp. 43-44).

Cupressocrinus abbreviatus GOLDF.

P1. 6, Fig. 4 
- Goldfuss [Goldfuss, 1839] Nov. Act. Ac. Leop. XIX p. 333 and Pl. 1, Figs. 3, 4.

- E. Schultze [L. Schultze, 1866] Echinodermen des Eifler Kalkes p. 19, P1. II and Pl. III, Fig. 4.

The often quoted Cupressocrinus abbreviatus belongs, together with Cupressocrinus inflatus, to the forms that exhibit a concentric sculpture of the plates that is the plates resemble the exterior shields of a turtle shell.

Cupressocrinus abbreviatus belongs to those species of the Eifel limestone, which possess a wider horizontal distribution. For example, in the Breslau collections there is a specimen which had been collected by FERDINAND ROEMER at Paffrath in 1844 (although it differs from the typical specimens by having a smooth surface and therefore should be separated as var. laevis).

The only calyx of the genus so far found in Asia belongs to the typical Cupressocrinus abbreviatus. The shallow-bowl shape and in particular the sculpture of the plates is exactly the same as in the European specimens; only the centro-dorsal portion (aboral side of the calyx) is preserved in the specimen from South China and that is somewhat smaller than that in the Eifel specimens, but hardly different from the specimens from the eastern side of the Rhine.

It has to be emphasized that with respect to its geography and stratigraphy the wide distribution of the species is of particular interest. Based on previous experience, crinoids appeared to have the narrowest geographic distribution of all Middle Devonian marine inhabitants, and for this reason the documentation of a Rhenish species in the Far East is important.

Cupressocrinus abbreviatus occurs at Gerolstein in the marls of the actual Crinoid Bed that is, at the base of the Stringocephalus Limestone comparatively rarely. Complete specimens are more common on weathered slabs in the fields between Gerolstein and Pelm. The stratigraphic level is the Stringocephalus Limestone, i.e., the zone above the Crinoid Bed. The same age must be assigned to the occurrence at Po-si in southern Yunnan. 


\title{
3.2. Translated explanation of plate six (Fig. 3)
}

\author{
Upper Devonian of southern Yunnan \\ Brachiopods corals crinoids
}

1a-c. Cyathophyllum ceratites Goldf. upper Middle Devonian. Lou-Néan 2:1. p. 41.

2a. Cyathophyllum hallioides Frech. upper Middle Devonian. Lou-Néan 2:1. p. 41.

2b. The same, Crinoid Bed, Urft, Eifel. Upper Devonian. p. 41.

3a, b. Cyathophyllum vermiculare Goldf. upper Middle Devonian. Lou-Néan 2:1. a) calyx, b) cross-section. p. 40.

4. Cupressocrinus abbreviatus. Po-Si, S. Yunnan. 1:1. p. 43.

5a, b. Retzia ulothrix mut. nov. sinensis. Upper Devonian. Tien-Sien-Kouang, S. Yunnan. p. 39.

6. Rhynchonella pugnus var. alta Cal. Ta-i-ti, S. Yunnan. p. 38, enlarged.

7. Retzia radialis mut. nov. praecursor. Upper Devonian. J-Léang, S. Yunnan. 2:1. p. 39.

8. Tornoceras simplex v. B. lower Upper Devonian. La-li-ha, S. Yunnan. 2:1. p. 39.

9a, b. Spirifer pachyrhynchus Vcn. Upper Devonian. Tien-Sien-Kouang. p. 37.

10. Spirifer Maureri. upper Middle Devonian. Si-Ni-Kao, S. Yunnan. p. 36.

11a, b. Spirifer Maureri. upper Middle Devonian. Finnentropp, Westfalen (orig. Scupin) p. 36.

Figs. 4-7, 9-11 in natural size.

\section{Taxonomy}

Current status of "Cupressocrinites" is under active revision. According to the crinoid Treatise, "Cupressocrinus" and "Halocrinites" are junior synonyms of “Cupressocrinites" (Moore and Lane, 1978, pp. T657-T658) without mentioning the occurrence in China. Bohatý (2005) subdivided the concept of "Cupressocrinites" into 
three genera: Cupressocrinites Goldfuss, 1839; Robustocrinites Bohatý, 2005; and Abbreviatocrinites Bohatý, 2005. "C. abbreviatus” collected by Richthofen should be interpreted as "A. abbreviatus". "C. deltoides" reported by Chen and Yao (1993) was synonymized with "A. inflatus inflatus" with a question mark (Bohatý, 2005, 2006). Webster et al. (2009) also questioned the taxonomic assignment of "C. deltoides". Bohatý and Herbig (2010) resurrected Halocrinites and placed "Abbreviatocrinites" as a junior synonym of Halocrinites. Thus, "C. abbreviatus" should be reinterpreted as H. schlotheimii Steininger, 1831; and "C. deltoides" should be H. inflatus inflatus (Schultze, 1866) (see Bohatý and Herbig, 2010).

According to Chen and Yao (1993), "C. deltoides" resembles the calyx of " $C$. abbreviatus" but differs in bearing three peripheral canals (Fig. 4C) in the column instead of four in the latter. This specimen contains modified oral plates known as the "consolidating apparatus" (Fig. 4E). Two arm plates (Fig. 4D) were glued to the missing clavicular plate. Based on these characters, "C. deltoides" reported by Chen and Yao (1993) is a junior synonym of Halocrinites sampelayoi, and the column taxon “Cupressocrinites yunnanensis" reported by $\mathrm{Mu}$ and $\mathrm{Wu}(1974)$ is not determinable on generic or species level (see Bohatý and Herbig, 2010) (J. Bohatý, personal communication, 09.2014).

\section{Discussion}

Based on the illustration (Fig. 3), it is clear that the same figure (Frech, 1911, pl. 6, fig. 4) of "Cupressocrinus abbreviatus" was reprinted in Tien and Mu (1955, pl. 48, fig. 12) and in Cao and Gui (1974, pl. 76, fig. 3). In the original description, Frech (1911) paid more attention to its similarity to European specimens and noticed the wide geographic distribution for this crinoid during the Devonian. He also stated that this specimen is not only the first "Cupressocrinus" calyx found in China, but also the first one in Asia. However, Reed (1908, p. 38, pl. 5, figs. 9, 9a, 10, 11, 11a) reported "Cupressocrinus schlotheimi" and "Cupressocrinus cf. crassus" from Burma before Frech's publication. On the other hand, Tien and Mu (1955) provided more systematic information about this crinoid. They identified it as a dicyclic crinoid and interpreted 
it as from the Middle Devonian strata in Yunnan Province.

$\mathrm{Mu}$ and $\mathrm{Wu}(1974)$ reported a new column taxon "Cupressocrinites yunnanensis" from the same unit on the basis of two specimens exhibiting four peripheral canals in the column (Fig. 4A, B). However, it is not identifiable at the generic or species level based on modern standards (J. Bohatý, personal communication, 09.2014).

Chinese translations of cupressocrinitids and/or "Cupressocrinites" vary through time (Table 1). Cao and Gui's (1974) translation of "C. abbreviatus" was probably misinterpreted from the Japanese translation of the family (see Yokoyama, 1920) because the Japanese meaning implied ball-shaped, not carpet-shaped as in Cao and Gui (1974). On the other hand, Mu and Wu (1974) gave a Chinese name on the basis of new material of cupressocrinitid column taxon. Chen and Yao (1993) proposed the Chinese name for the second Chinese cupressocrinid calyx (Table 1). In summary, "Cupressocrinites" had been used and translated into Chinese/Japanese several times in the past (see the second part in Table 1). However, these names are not the best for reflecting the meaning of the original Latin name in terms of modern Chinese. For the purpose of future reference, standardized Chinese names for Cupressocrinitidae are suggested here (last entry in the Table 1).

On the other hand, although Frech's (1911) work was listed in Grabau (1924), it is not well recognized by some western crinoid workers (e.g., Bassler and Moodey, 1943; Webster, 2003; Webster and Webster, 2014). Note that this work was cited in Webster et al. (2009) but not mentioned in the chronological list of Paleozoic echinoderm studies from China. This study provides an update on documentation of cupressocrinitids from China.

\section{Conclusions}

After this study, several points can be made with certainty. 1) A figured Chinese crinoid calyx was collected by F. von Richthofen during his travel to China before 1894 (see 2.3. Prologue above). 2) Frech completed its description in 1911, and the same figure has been reprinted in Tien and Mu (1955) and Cao and Gui (1974). 3) Although the systematic position of "C. abbreviatus" has been reinterpreted as $H$. 
schlotheimii, Richthofen's specimen remains the oldest cupressocrinitid calyx reported from China. 4) No photograph of Richthofen's specimen is known at present, but discoveries of additional cupressocrinitd columnals by $\mathrm{Mu}$ and $\mathrm{Wu}(1974)$ and a second cupressocrinitid calyx "C. deltoides" (= Halocrinites sampelayoi) by Chen and Yao (1993) from the same general area confirm the existence of this family in China.

\section{Acknowledgements}

Thanks to the guest editor W. I. Ausich, G. D. Webster and J. Bohatý for their constructive reviews and comments. This work was supported by National Science Foundation of China (41240015) and State Key Laboratory of Palaeobiology and Stratigraphy (20131103). F. T. Fürsich acknowledges a CAS Visiting Professorship for Senior International Scientists and the hospitality of the Nanjing Institute of Geology and Palaeontology, CAS. Many thanks to librarians Xiao-Ping Zhang and Man Feng for the access to the rare book collection; Dao-Jun Yuan for the access to the type specimen; Zhou-Qing Chen for taking digital images of the specimens at NIGP.

\section{References}

Bassler, R.S., Moodey, M.W., 1943. Bibliographic and faunal index of Paleozoic pelmatozoan Echinoderms. Geological Society of America Special Paper 45, $1-734$.

Bohatý, J., 2005. Doppellagige Kronenplaten: Ein neues anatomisches Merkmal paläozoischer Crinoiden und Revision der Familie Cupressocrinitidae (Devon). Paläontologische Zeitschrift 79 (2), 201-225.

Bohatý, J., 2006. Neue Cupressocrinitidae (Crinoidea) aus den mitteldevonischen Kalkmulden der Eifel (linksrheinisches Schiefergebirge, Deutschland) [New Cupressocrinitidae (Crinoidea) from the Middle Devonian of the Eifel Hills (western Rhenish Slate Massif, Germany)]. Senckenbergiana Lethaea 86, 151-189. 
Bohatý, J., Herbig, H.G., 2010. Middle Givetian echinoderms from the Schlade Valley (Rhenish Massif, Germany): habitats, taxonomy and ecostratigraphy. Paläontologische Zeitschrift 84, 365-385.

Cao, R.G., Gui, M.Y., 1974. Echinodermata. In: Geological Bureau of Yunnan Province (Ed.), Fossils of Yunnan Province, Two Volumes. People's Press of Yunnan, Kunming, pp. 709-730 (in Vol. One), pl. 76, fig. 3, pl. 240, figs. 9-12, pl. 243, fig. 9 (in Vol. Two) (in Chinese; internal publication).

Chang, H.T., 1937. History of Geological Studies in China. The Commercial Press, Shanghai, 149 pp. (in Chinese).

Chen, Z.T., Yao, J.H., 1993. Palaeozoic Echinoderm Fossils of Western Yunnan, China. Geological Publishing House, Beijing, 102 pp. (in Chinese).

Dames, W., 1883. Kamrische trilobiten von Liautung. In: Richthofen, F. von (Ed.), China, Fourth Volume. Verlag Dietrich Reimer, Berlin, pp. 3-33.

Frech, F., 1911. Das Devon Chinas. In: Richthofen, F. von (Ed.), China, Fifth Volume. Verlag Dietrich Reimer, Berlin, pp. 18-58.

Goldfuss, G.A., 1839. Beitäge zur Petrefactenkunde, Acta Natur. Curiosorum. Nova Acta Physico-medica Academie Caesar Leopoldino-Carolinae Naturae Curiosorum 19 (1), 329-364.

Grabau, A.W., 1924. Stratigraphy of China, Part I: Palaeozoic and Older. Geological Survey, Ministry of Agriculture and Commerce, Peking, 528 pp.

Gu, Z.G., Li, X.B. (Eds.), 2000. Fossils. Anno Domini Media Co. Ltd., Guangzhou, 319 pp. ( $2^{\text {nd }}$ edition, $3^{\text {rd }}$ printing in 2007; in Chinese) (translated from Walker, C., Ward, D., 1992. Fossils. Dorling Kindersley Limited, London, 320 pp.).

Kayser, E., 1883a. Mittel- und Obersilurisch Versteinerungen aus dem Gebirgsland von Tschau-tiën im nordöstlichen Theil der Provinz Sz'-tshwan. In: Richthofen, F. von (Ed.), China, Fourth Volume. Verlag Dietrich Reimer, Berlin, pp. 37-49.

Kayser, E., 1883b. Obercarbonische fauna von Lo-ping. In: Richthofen, F. von (Ed.), China, Fourth Volume. Verlag Dietrich Reimer, Berlin, pp. 160-208.

Lin, J.P., 2015. Treasure with blood: on the discovery of Traumatocrinus (Echinodermata, Triassic) crowns in China. Palaeoworld, this issue. 
Moore, R.C., Lane, N.G., 1978. Superfamily Cupressocrinitacea Roemer, 1854. In:

Moore, R.C., Teichert, C. (Eds.), Treatise on Invertebrate Paleontology. Part T.

Echinodermata 2. Crinoidea 2. The Geological Society of America and University of Kansas Press, Boulder and Lawrence, pp. T656-T658.

Mu, A.T. (= Mu, E.Z.), 1948. Fossil crinoids from China. Geological Review 13, 55-66 (in Chinese).

Mu, E.Z., Wu, Y.R., 1974. Devonian crinoids. In: Nanjing Institute of Geology and Palaeontology, Academia Sinica (Ed.), Handbook of Stratigraphy and Palaeontology of the South-western Region. Science Publishing House, Beijing, p. 247 (in Chinese).

Peng, S.C., 2007. Historical review of trilobite research in China. In: Mikulic, D.G., Landing, E., Kluessendorf, J. (Eds.), Fabulous Fossils - 300 Years of Worldwide Research on Trilobites. New York State Museum, New York, pp. 171-191.

Reed, F.R.C., 1908. The Devonian faunas of the Northern Shan states. Palaeontologia Indica, New Series 2 (5), 1-183.

Schultze, L.J.T., 1866. Monographie der Echinodermen des Eifler Kalkes. Carl Gerold's Sohn, Wien, 118 pp.

Steininger, J., 1831. Bemerkungen über die Versteinerungen, welche in dem Übergangskalkgebirge der Eifel gefunden werden. Lints, Trier, 44 pp.

Tien, C.C., Mu, A.T., 1955. Crinoidea. In: Chen, X. and others (Eds.), Index Fossils of China, Invertebrates, Volume One. Geological Publishing House, Beijing, pp. $89-95$ ( $2^{\text {nd }}$ printing in 1957 ; in Chinese).

Wang, L.W., Zhang, R.S., Chang, A.Z., Yan, E.Z., Wei, X.Y. (Eds.), 1955. Handbook of Index Fossils in China. Department of Publishing, Local Branch of Government-Owned Nanjing New Life Factory, Nanjing, 475 pp. (in Chinese).

Wang, L.W., Zhang, R.S., Chang, A.Z., Yan, E.Z., Wei, X.Y. (Eds.), 1956. Handbook of Index Fossils in China. New Knowledge Press, Shanghai, 669 pp. (in Chinese).

Webster, G.D., 2003. Bibliography and index of Palaeozoic crinoids, coronates, and hemistreptocrinoids, 1758-1999. Geological Society of America Special Paper 363 (online only). 
Webster, G.D., Webster, D.W., 2014. Bibliography and Index of Paleozoic Crinoids, Coronates, and Hemistreptocrinoids, 1758-2012. Published by Author, Pullman, Washington, 2694 pp. (http://crinoids.azurewebsite.net)

Webster, G.D., Waters, J.A., Chen, X.Q., 2009. Revision of the Chen and Yao

Devonian to Perrmian crinoids from Western Yunnan. Palaeobiodiversity and Palaeoenvironments 89, 119-160.

Yokoyama, Y., 1920. Outline of Paleontology. Waseda University Press, Tokyo, 657 pp. (in Japanese).

\section{Table/Figure Captions}

Table 1. Chinese translations of cupressocrinitids.

Fig. 1. (A) Front cover of the book China, Fifth Volume by Frech (1911) showing a stone turtle carrying a tablet. (B) A Ming-Dynasty example of the stone turtle (ca. 1465-1487 A.D.) at Chaotian Palace, Nanjing, China.

Fig. 2. The title page of the book China, Fifth Volume by Frech (1911).

Fig. 3. Reproduction of the plate six in the book China, Fifth Volume by Frech (1911). Note fig. 4 is the crinoid calyx mentioned in this study.

Fig. 4. Cupressocrinitid specimens reported from Yunnan, China. (A, B) Column taxon "Cupressocrinites yunnanensis" Mu and Wu, 1974; (A) NIGP22887; (B) NIGP222888. (C-E) Holotype (No. 403) of “C. deltoides” (= Halocrinites sampelayoi) from western Yunnan (Chen and Yao, 1993); (C) aboral view showing three peripheral canals (note that partitions between central and external axial canals not preserved; multilamellar exobasal- and exoradial layers strongly weathered; multilamellar 
exobrachial layers partly preserved; J. Bohatý, personal communication, 09.2014); (D) lateral view with two arm plates affixed to the missing clavicular plate; (E) top view showing the consolidating apparatus (arrow). Scale bars $=5 \mathrm{~mm}(\mathrm{~A}-\mathrm{D}) ; 3 \mathrm{~mm}(\mathrm{E})$. Specimens are deposited at the Nanjing Institute of Geology and Paleontology (NIGP), Nanjing, China. 


\begin{tabular}{|c|c|c|}
\hline English or Latin names & Chinese translations & Reference \\
\hline Cupressocrinidae* & 苸海百合科 & Yokoyama, 1920 \\
\hline "Cupressocrinus" sp. & 松毢海百合 & Wang et al., 1955 \\
\hline "Cupressocrinites abbreviatus" & 缩短毯海百合 & Cao and Gui, 1974 \\
\hline "Cupressocrinites yumnanensis" & 云南柏果海百合 & Mu and $\mathrm{Wu}, 1974$ \\
\hline "Cupressocrinites deltoides" & 三角形松球海百合 & Chen and $\mathrm{Yao}, 1993$ \\
\hline "Cupressocrinites" & 㲑海百合 & derived from Yakoyama, 1920 \\
\hline "Cupressocrinites" & 毯海百合 & Cao and Gui, 1974 \\
\hline "Cupressocrinites" & 柏果海百合 & Mu and $\mathrm{Wu}, 1974$ \\
\hline "Cupressocrinites" & 松球海百合 & Chen and $\mathrm{Yao}, 1993 ; \mathrm{Gu}$ and $\mathrm{Li}, 2000$ \\
\hline Cupressocrinitidae & 松果海百合科 & this study \\
\hline
\end{tabular}

*should be Cupressocrinitidae 


\title{
CHINA.
}

\section{ERGEBNISSE EIGENER REISEN}

\author{
UNB
}

DARAUE GEGRUNDETER STUDIEN

yox

\section{FERDINAND FREIHERRN v. RICHTHOFEN}

\section{FUNFTER BAND}

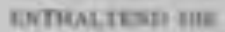

ABSCHL IFSSENDE RALAEONTOLOGISCHE HFARBETUNG DER SAMM. LUNGES $F$ VON RICHTHOFENS, DIE UNTERSUCHUNG WETTERER FOSSIL.FR RESTK AUS DEN VON IHM REREISTEN IROVINZEN SOWTK DEN ENTWURF EINER ERDGESCHICHTLICHEN UEHEKSICHT CHINA'S vos

DR. FRITZ FRECH.

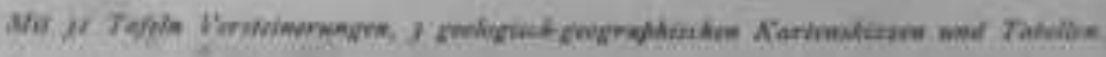


- Brtmintentyroh. Gima V.

Taiet 5
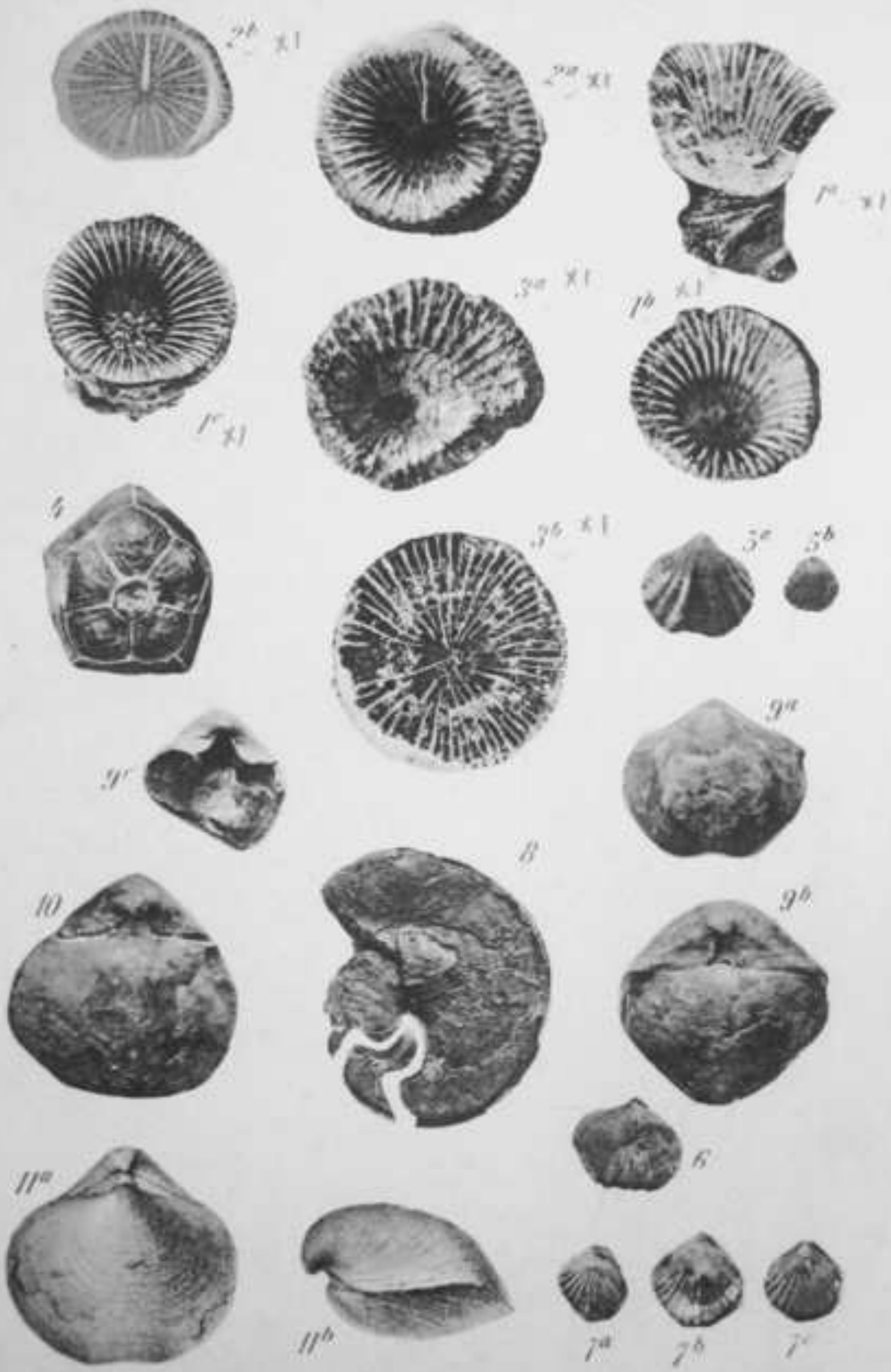
